\title{
A biologically relevant habitat condition index for streams in northern Portugal
}

\author{
S.V. OLIVEIRA* and R.M.V. CORTES \\ Universidade de Trás-os-Montes e Alto Douro, Departamento Florestal, Apart. 1013, 5001-911 Vila Real, Portugal
}

\begin{abstract}
1. This study describes the development of an index for assessing stream habitats in northern Portugal at a variety of spatial scales and levels of perturbation. In developing the index, 86 environmental variables, including regional and local ones, were used to reflect the geomorphological characteristics, riverine habitat, and human activities occurring in each basin.

2. Collections of benthic invertebrates were made at each sample site. To reflect the observed variation in assemblages, the streams were separated into two categories: the North-west catchments and the Douro catchments.

3. Multivariate analysis techniques applied to the physical and biological data sets allowed the determination of the relative importance of local and regional environmental descriptors in the discrimination of the invertebrate assemblages.

4. Successive statistical refinement procedures yielded 10 variables, all at the local scale. Variation along disturbance gradients allowed the development of a habitat index through scoring criteria that separated reference sites from stressed sites.

5. The results indicate the reduced impact of catchment factors by a buffering influence probably resulting from the presence of a riparian corridor.

Copyright (C) 2005 John Wiley \& Sons, Ltd.
\end{abstract}

KEY WORDS: ecological status; invertebrates; catchments; stream condition; environmental indicators; habitat assessment

\section{INTRODUCTION}

Evaluation of river health often involves assessments that make a link between biota and the environment. For rivers, two main procedures are used. The first uses models that predict the occurrence of invertebrate or fish taxa at a wide range of impacted sites based on their association with environmental variables (e.g. Wright, 1995; Reynoldson et al., 1997; Oberdorff et al., 2001). The second, using multimetric systems based on ecologically relevant attributes of the status of assemblages (metrics) that are sensitive to stressors, provides a response that can be separated from natural variation (Barbour et al., 1999). Both of these approaches provide a way of comparing new sites with a reference situation characterized by the natural or

*Correspondence to: S.V. Oliveira, Universidade de Trás-os-Montes e Alto Douro, Departamento Florestal, Apart. 1013, 5001-911 Vila Real, Portugal. E-mail: simonev@utad.pt 
near-natural condition of water quality and habitat features. Development of biological indices that reflect river conditions can be used to compare scores between impacted sites and those not under stress (Scott and Hall, 1997; Oberdorff et al., 2002). However, it is often more practical to describe the condition of river systems using habitat indices, since they indirectly reflect changes in the aquatic communities in response to human pressures.

Several river habitat indices have been developed in order to incorporate comparisons with reference or target conditions, including River Habitat Survey (Raven et al., 1997), the United States Environment Protection Agency Rapid Bioassessment Protocols (Plafkin et al., 1989; Barbour et al., 1999), and the index of Davis et al. (2000) used to predict local habitat features from catchment variables. There are models that use biologically relevant habitat parameters which can usefully measure the dependence of aquatic populations on these variables. These models are generally based on micro-habitat assessment for target species and are not directed at a whole community. For example, PHABSIM (Physical Habitat Simulation System-Milhous et al., 1984) involves measurements of channel shape, water depth, velocity, substrate and cover to describe micro-habitat availability for a defined species list. Bowlby and Roff (1986) developed the Habitat Quality Index (HQI) which relates habitat variables representing food, shelter, stream flow and temperature for trout populations. HABSCORE (Milner et al., 1985, 1998) is a similar method, designed to predict salmonid abundance from habitat parameters.

The habitat index presented in this paper adopts the principles of reference conditions and their relationship with aquatic organisms. However, a framework of multimetric methods was adopted for the calibration and aggregation of the selected environmental variables into an index. The reference status was also defined in conjunction with the pristine communities of benthic assemblages. This results in a broader application, since it is not created only for target species.

Patterns and processes observed in aquatic communities are determined not only by local mechanisms, but also by processes operating at a larger scale, such as hydrological units (Oberdorff et al., 2001), geology (Corkum, 1989), geomorphology (Downs and Brooks, 1994), climate (Hughes et al., 1994) and land use (Imhof et al., 1996). Because these large-scale factors interact with local factors, a river needs to be examined at different scales ordered into a hierarchy, from the micro-habitat to the catchment level, each with a different degree of sensitivity and recovery time (Frissell et al., 1986). The index presented here attempts to incorporate instream features together with variables from beyond the main river channel. A hierarchy of variables potentially influencing benthic assemblages were considered as possible causeresponse linkages for both physical and water-quality parameters.

Stream managers often require information about the physical features of a river in need of improvement in order to define passive or active strategies for restoration (McIver and Starr, 2001) and to evaluate the success of such strategies in enhancing the biota (Reeves et al., 1997). The Portuguese river authority-National Water Institute (INAG) - is taking the first steps in stream rehabilitation and requires tools to assess the effectiveness of schemes before and after work has taken place. The index described here is designed to support and satisfy that requirement by establishing clear links between the aquatic biota and physical features.

\section{METHODS}

\section{Study area}

The study was conducted in northern Portugal (Figure 1). It included the catchments of the rivers Lima, Cávado and Ave, here described as North-west (NW), and the Portuguese part of the Douro catchment. Each catchment corresponds to distinct river basin districts (RBDs), which have their own catchment plans. The main characteristics of the two RBDs are summarized in Table 1 and show that there is intensive 


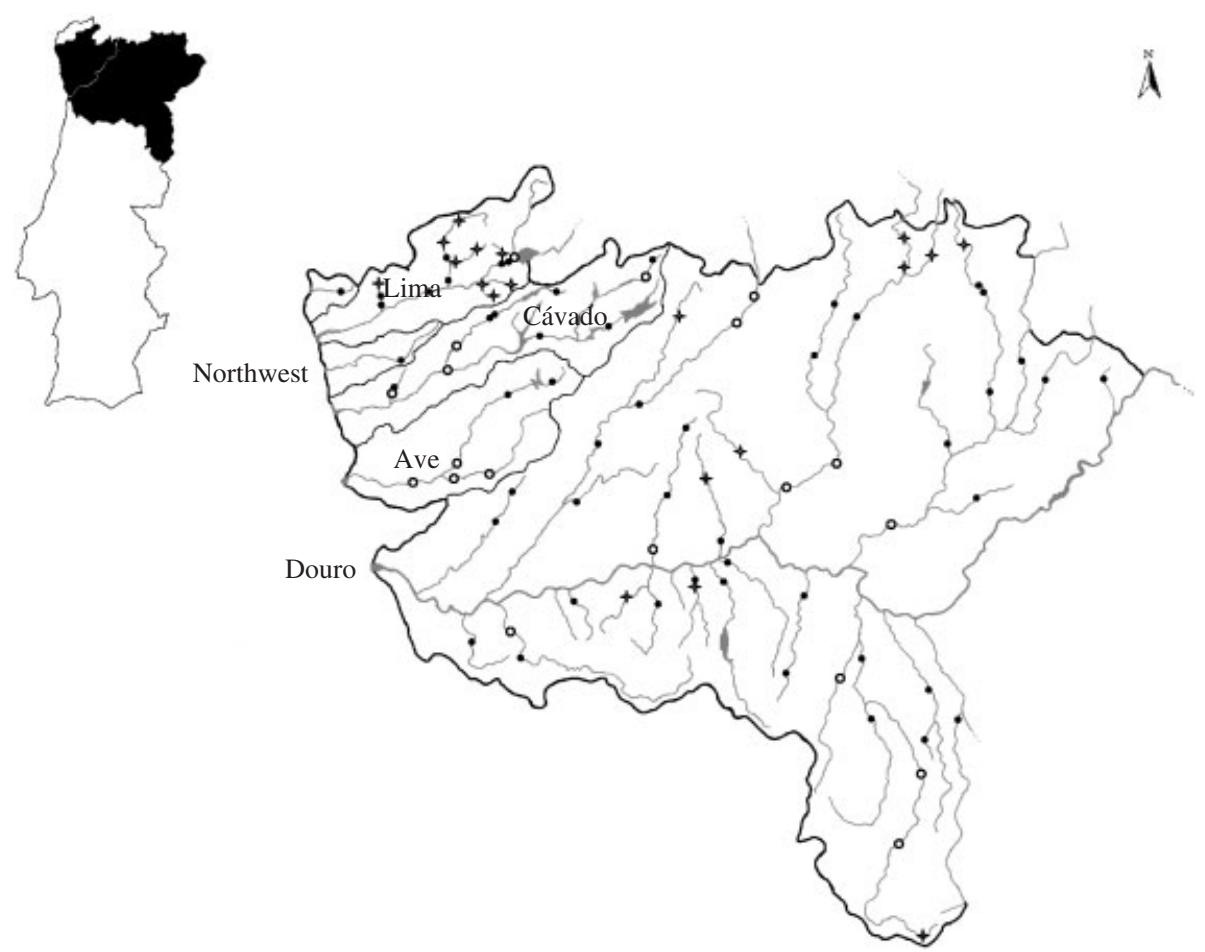

Figure 1. Location of the North-west and Douro catchments in Portugal, showing sampled sites used in the development of the habitat index. Reference $(+)$ and impaired sites $(O)$ are illustrated.

Table 1. Main characteristics of the Douro and NW catchments in northern Portugal

\begin{tabular}{|c|c|c|}
\hline Characteristics & Douro & NW \\
\hline Geology & Granite and schist & Granite \\
\hline Valley shape & Steep valleys in the upland areas & $\begin{array}{l}\text { Narrow, high-gradient valleys along the entire } \\
\text { river network }\end{array}$ \\
\hline Rainfall & $\begin{array}{l}>1400 \mathrm{~mm} \mathrm{yr}^{-1} \text { in the mountainous northern } \\
\text { areas and }<500 \mathrm{~mm} \mathrm{yr}^{-1} \text { in semi-arid central part }\end{array}$ & $\begin{array}{l}\text { Average }>1900 \mathrm{~mm} \mathrm{yr}^{-1} \text {; ca } 2800 \mathrm{~mm} \mathrm{yr}^{-1} \text { in the } \\
\text { headwaters }\end{array}$ \\
\hline \multirow[t]{2}{*}{ Land use } & Areas dominated by agro-forestry & $\begin{array}{l}\text { Dominated by agriculture in the flatter western } \\
\text { areas and forest in the highest zones. Higher } \\
\text { population density than the Douro }\end{array}$ \\
\hline & $\begin{array}{l}\text { Low population density, except near the river } \\
\text { mouth }\end{array}$ & \\
\hline Main impacts & $\begin{array}{l}\text { Low human influence except in the coastal strip } \\
\text { where urban pressures create environmental } \\
\text { problems with impacts on running waters } \\
\text { River Douro is highly regulated }\end{array}$ & $\begin{array}{l}\text { The coastal area has the largest human population } \\
\text { density in Portugal. Domestic sewage treatment } \\
\text { hardly reaches a level of } 50 \% \text { of all settlements } \\
\text { Ave basin has relatively high concentration of } \\
\text { industry (mainly textile factories) }\end{array}$ \\
\hline
\end{tabular}


human impact in the downstream areas of both catchments, whereas river regulation (due to impoundment structures for hydropower purposes) is more widespread. Flow conditions are relatively higher and less variable in the NW RBD due to the Atlantic influence, which, in conjunction with the steep gradients, creates fast-flowing streams. Urban development and intensive agriculture are less represented in the Douro catchment.

\section{Data collection}

The data set consisted of 90 samples (one per site), 36 and 54 respectively in the NW and in the Douro catchments, taken from 47 streams (Figure 1) covering the whole range of environmental conditions. Ecological information included benthic biota, physical habitat and water quality assessment. Surveys were carried out during the spring/summer of 1999 in the NW catchments and in 1997 in the Douro basin. Benthic invertebrates were collected using a kick net ( $350 \mu \mathrm{m}$ mesh aperture) with a constant effort of $5 \mathrm{~min}$ (CPUE). Each habitat (e.g. riffle, pool, edge) was sampled in proportion to its representation at the site. Wherever possible, the organisms were identified to species level, with the exceptions of Hydracarina (order), Diptera (family, or sub-family for Chironomidae) and Oligochaeta (family). All organisms were counted.

Environmental variables at different spatial scales, including those associated with human activities, were recorded to develop a method for assessing the stream habitats of all the catchments in northern Portugal. The data represent 85 environmental variables, which can be divided into 36 regional and 49 local categories, the latter comprising reach and valley variables. Names and abbreviations of each variable, units and expected response to increasing perturbation are presented in Table 2. This table shows that there is a higher level of human impact in the NW RBD, at the two spatial scales, in spite of its relative hydrological stability.

Disturbance in the catchment was assessed in relation to the removal and destruction of habitat, clearance of stream-bank vegetation, alien plant species, forestry and road building, regulation of rivers, sedimentation from land clearance, diffuse pollution, and point-source pollution from industry, urban development and mining. Measurements of local environmental variables took place along the same $100 \mathrm{~m}$ stretch used for biological data collection. Valley-scale variables were based on a standard $2 \mathrm{~km}$ length, comprising the area that directly influences the river channel. Regional environmental variables were measured for the whole catchment upstream of the sample site.

Reach and valley variables describing local conditions were evaluated in the context of instream and surrounding habitat features, water quality, flow regime, aquatic and riparian vegetation, energy sources, land use, artificial modifications of the channel, banks and valley, location and climate. The regional variables were expressed in terms of geomorphological characteristics, land cover, chemical contamination from diffuse sources, impoundment effects, and urban and industrial impacts.

\section{Data analysis}

\section{Selecting and testing environmental variables}

Since the aim of this study was to create an index that accurately measures and diagnoses the cumulative impacts of multiple stressors through a small group of variables, the first step was to select those variables representative of the various scales that explained most of the variance in species composition. For this purpose, a canonical correspondence analysis (CCA) was performed using CANOCO (ter Braak and Smilauer, 1998). CCA is a method of direct gradient analysis, where the ordination of objects (sites) is based simultaneously on species data and on associated environmental information (Jongman et al., 1987; ter Braak and Prentice, 1988). Only those variables with a variation inflation factor (VIF) less than 20 were included, to avoid multicollinearity (ter Braak, 1986). Multiple CCAs were necessary to obtain a restricted 
Table 2. Environmental variables at regional and local scale measured at 90 sites in northern Portugal and used in the construction of the $\mathrm{HCI}^{\mathrm{a}}$. Variables marked with an asterisk are least likely to be affected by human activities

\begin{tabular}{|c|c|c|c|c|c|}
\hline \multirow[t]{2}{*}{ Environmental variables } & \multicolumn{2}{|l|}{ Douro } & \multicolumn{2}{|l|}{ NW } & \multirow{2}{*}{$\begin{array}{l}\text { Expected } \\
\text { to increas } \\
\text { turbation }\end{array}$} \\
\hline & Mean & SD & Mean & SD & \\
\hline \multicolumn{6}{|l|}{ Local variables } \\
\hline \multicolumn{6}{|l|}{ Instream and surrounding topographical features } \\
\hline *Mean water depth, $h(\mathrm{~cm})$ & 55.8 & 35.5 & 63.2 & 27.7 & \\
\hline *Maximum water depth, hmax $(\mathrm{cm})$ & 101.8 & 55.6 & 132.6 & 58.8 & \\
\hline Mean water velocity, $v\left(\mathrm{~m} \mathrm{~s}^{-1}\right)$ & 9.22 & 11.52 & 35.56 & 40.67 & Decrease \\
\hline Maximum water velocity, $\operatorname{vmax}\left(\mathrm{m} \mathrm{s}^{-1}\right)$ & 32.77 & 30.02 & 70.50 & 63.56 & Decrease \\
\hline *Mean wetted channel width, $w(\mathrm{~m})$ & 13.06 & 12.36 & 24.05 & 31.90 & \\
\hline *Stream width:depth ratio, $w / h$ & 24.41 & 17.65 & 39.15 & 60.33 & \\
\hline Substratum size class $(\%)$ & & & & & Decrease \\
\hline bedrock, \%rock & 17.8 & 22.5 & 11.7 & 21.2 & \\
\hline boulder, \% bould & 20.1 & 15.4 & 22.8 & 22.9 & \\
\hline cobble, $\%$ cob & 22.0 & 16.8 & 13.3 & 14.7 & \\
\hline gravel, $\%$ gravel & 16.8 & 14.4 & 7.8 & 9.6 & \\
\hline sand, $\%$ sand & 15.7 & 15.6 & 30.0 & 28.7 & \\
\hline slime, $\%$ slime & 0.2 & 1.4 & 0.7 & 4.2 & \\
\hline clay, \% clay & 7.4 & 12.4 & 13.8 & 29.9 & \\
\hline Percentage of dominant substrate, $\%$ domS & 45.3 & 13.4 & 59.4 & 20.3 & Increase \\
\hline Channel quality, GQC & 28.8 & 4.6 & 25.8 & 5.6 & Decrease \\
\hline Habitat modification score, HMS & 6.3 & 4.1 & 6.6 & 4.4 & Increase \\
\hline Morphological condition, MC (categories 1-5) & 1 & - & 1 & - & Increase \\
\hline *Mean stream slope, Ss $\left(\mathrm{m} \mathrm{km}^{-1}\right)$ & 20.6 & 11.6 & 63.1 & 60.0 & \\
\hline Sediment load segment, SLS (categories 1-5) & 2 & - & 2 & - & Increase \\
\hline $\begin{array}{l}\text { *Predominant form of the valley, PFV (cate- } \\
\text { gories } 1-7 \text { ) }\end{array}$ & 2 & - & 1 & - & \\
\hline \multicolumn{6}{|l|}{ Water quality parameters } \\
\hline $\mathrm{pH}$ & 6.90 & 0.76 & 6.61 & 0.66 & Variable \\
\hline Dissolved oxygen, $\mathrm{O}_{2}\left(\mathrm{mg} \mathrm{L}^{-1}\right)$ & 9.76 & 2.08 & 8.81 & 1.59 & Decrease \\
\hline Percentage of dissolved oxygen, $\% \mathrm{O}_{2}$ & 99.2 & 23.0 & 91.0 & 13.7 & Decrease \\
\hline Water temperature, temp $\left({ }^{\circ} \mathrm{C}\right)$ & 20.53 & 2.98 & 17.41 & 3.75 & Increase \\
\hline Turbidity, turb (categories 1-4) & 3 & - & 3 & - & Increase \\
\hline Conductivity, cond $\left(\mu \mathrm{S} \mathrm{cm}^{-1}\right)$ & 118.54 & 77.65 & 81.52 & 123.63 & Increase \\
\hline \multicolumn{6}{|l|}{ Flow regime } \\
\hline Hydrological regime, HR (categories $1-5$ ) & 1 & - & 1 & - & Increase \\
\hline Stream flow, $F(\mathrm{~mm})$ & 356.48 & 240.88 & 1170.83 & 426.68 & Variable \\
\hline \multicolumn{6}{|l|}{ Aquatic vegetation } \\
\hline Aquatic vegetation covering, $\%$ aquC & 23.8 & 28.0 & 12.5 & 19.6 & Increase \\
\hline \multicolumn{6}{|l|}{ Riparian vegetation } \\
\hline Riparian canopy cover, \%ripC & 35.4 & 32.8 & 22.2 & 28.1 & Decrease \\
\hline Herbaceous covering, $\%$ herbC & 33.4 & 25.2 & 44.0 & 33.1 & Variable \\
\hline Structure of arboreal vegetation, SAV & 16.0 & 8.1 & 14.5 & 7.8 & Decrease \\
\hline Riparian vegetative zone width, RW & 4.1 & 3.0 & 2.5 & 2.1 & Decrease \\
\hline Influence of riparian vegetation structure, IRS & 6.2 & 3.6 & 6.6 & 4.3 & Decrease \\
\hline Riparian vegetation richness, $R R$ & 2.5 & 1.1 & 3.4 & 1.7 & Variable \\
\hline Integrity of riparian vegetation, IR & 12.6 & 5.6 & 11.6 & 6.3 & Decrease \\
\hline Riparian habitat quality, QBR & 70.2 & 22.0 & 56.1 & 26.5 & Decrease \\
\hline
\end{tabular}


Table 2 continued

\begin{tabular}{|c|c|c|c|c|c|}
\hline \multirow[t]{2}{*}{ Environmental variables } & \multicolumn{2}{|l|}{ Douro } & \multicolumn{2}{|l|}{ NW } & \multirow{2}{*}{$\begin{array}{l}\text { Expected response } \\
\text { to increasing per- } \\
\text { turbation }\end{array}$} \\
\hline & Mean & SD & Mean & SD & \\
\hline Riparian zone segment, RZS (categories 1-5) & 3 & - & 2 & - & Increase \\
\hline \multicolumn{6}{|l|}{ Energy sources } \\
\hline $\begin{array}{l}\text { Organic particulate matter, Debris (categories } \\
1-5)\end{array}$ & 1 & - & 5 & - & Decrease \\
\hline \multicolumn{6}{|l|}{ Land use } \\
\hline Marginal land-use, MLU & 14.9 & 5.5 & 18.5 & 5.8 & Decrease \\
\hline Land-use segment, LUS (categories 1-5) & 2 & - & 2 & - & Increase \\
\hline Urbanization segment, US (categories 1-5) & 2 & & 1 & & Increase \\
\hline \multicolumn{6}{|l|}{$\begin{array}{l}\text { Artificial modifications to the channel, banks and } \\
\text { valley }\end{array}$} \\
\hline Anthropogenic perturbation, anthP & 4.6 & 3.6 & 6.4 & 4.7 & Increase \\
\hline Bank alterations, Bank alt (categories 1-5) & 1 & - & 1 & - & Increase \\
\hline \multicolumn{6}{|l|}{ Location } \\
\hline *Altitude, Altitude (m) & 373.3 & 224.8 & 222.7 & 276.0 & \\
\hline *Longitude, Long (m) & 265759 & 44436 & 182600 & 18692 & \\
\hline *Latitude, Lat $(\mathrm{m})$ & 480325 & 41797 & 528623 & 18621 & \\
\hline \multicolumn{6}{|l|}{ Climate } \\
\hline${ }^{*}$ Mean daily air temperature, Tair $\left({ }^{\circ} \mathrm{C}\right)$ & 13.5 & 1.8 & 13.0 & 1.9 & \\
\hline *Mean annual precipitation, Prec (mm) & 874.1 & 295.5 & 1894.4 & 432.2 & \\
\hline \multicolumn{6}{|l|}{ Regional variables } \\
\hline \multicolumn{6}{|l|}{ Geomorphological characteristics } \\
\hline${ }^{*}$ Distance from source, distS $(\mathrm{km})$ & 44.6 & 34.7 & 25.1 & 21.1 & \\
\hline *Stream order, SO & 3.3 & 1.0 & 2.8 & 1.1 & \\
\hline *Zonation, Z (categories 1-6) & 2 & - & 1 & - & \\
\hline *Catchment area, $A\left(\mathrm{~km}^{2}\right)$ & 568.2 & 798.3 & 355.0 & 557.3 & \\
\hline${ }^{*}$ Catchment area class, A (cat) (categories 1-4) & 3 & - & 2 & - & \\
\hline *Relief ratio, $\mathrm{Rr}$ & 27.6 & 15.8 & 73.3 & 78.4 & \\
\hline *Total stream length, totL $(\mathrm{km})$ & 303.4 & 483.5 & 162.8 & 241.7 & \\
\hline${ }^{*}$ Catchment length, $\mathrm{L}(\mathrm{km})$ & 33.7 & 22.6 & 23.5 & 22,2 & \\
\hline *Form ratio, Fr & 0.42 & 0.22 & 0.67 & 0.82 & \\
\hline *Elongation ratio, Er & 0.71 & 0.18 & 0.84 & 0.39 & \\
\hline *Drainage density, Dd $\left(\mathrm{km} \mathrm{km}^{-2}\right)$ & 0.49 & 0.12 & 0.44 & 0.17 & \\
\hline *Mean catchment slope, $\mathrm{Sb}$ & 0.50 & 0.26 & 0.74 & 0.34 & \\
\hline \multicolumn{6}{|l|}{ Land cover } \\
\hline \multicolumn{6}{|l|}{ Relative proportions of catchment land-use } \\
\hline Forest, \%Forest & 30.4 & 10.6 & 30.4 & 7.6 & Decrease \\
\hline Uncultivated land, \%Uncult & 31.3 & 8.5 & 33.9 & 14.3 & Decrease \\
\hline Unproductive, \% Unprod & 3.2 & 3.4 & 8.3 & 8.0 & Variable \\
\hline Agriculture, $\% \mathrm{Ag}$ & 33.2 & 9.4 & 22.8 & 9.2 & Increase \\
\hline Social area, $\%$ Soc & 1.5 & 2.0 & 3.4 & 2.6 & Increase \\
\hline Hardwood:Softwood ratio, Hard/Soft & 4.8 & 21.7 & 3.3 & 4.6 & Variable \\
\hline Kilometres of roads, Road & 322.9 & 389.2 & 320.9 & 480.1 & Increase \\
\hline Percentage of burned area, $\% \mathrm{Ba}$ & 0.6 & 0.5 & 1.2 & 0.7 & Increase \\
\hline
\end{tabular}


HABITAT CONDITION INDEX FOR STREAMS IN PORTUGAL

Table 2 continued

\begin{tabular}{|c|c|c|c|c|c|}
\hline \multirow[t]{2}{*}{ Environmental variables } & \multicolumn{2}{|l|}{ Douro } & \multicolumn{2}{|l|}{ NW } & \multirow{2}{*}{$\begin{array}{l}\text { Expected response } \\
\text { to increasing per- } \\
\text { turbation }\end{array}$} \\
\hline & Mean & SD & Mean & SD & \\
\hline Chemical contamination from non-point sources & & & & & Increase \\
\hline Nitrogen, $\mathrm{N}\left(\mathrm{kg} \mathrm{yr}^{-1} \mathrm{ha}^{-1}\right)$ & 1.94 & 0.96 & 3.56 & 1.11 & \\
\hline Phosphorus, $\mathrm{P}\left(\mathrm{kg} \mathrm{yr}^{-1} \mathrm{ha}^{-1}\right)$ & 2.85 & 1.25 & 2.69 & 1.49 & \\
\hline Number of heads of cattle & & & & & Increase \\
\hline Bovine, Bov & 3997.5 & 5119.7 & 4056.6 & 6269.5 & \\
\hline Swine, $\mathrm{Sw}$ & 3613.2 & 5026.9 & 2118.0 & 3449.7 & \\
\hline Ovine, Ov & 11956.9 & 21167.4 & 2478.7 & 3331.4 & \\
\hline Caprine, Cap & 2798.2 & 4134.7 & 1807.5 & 3157.5 & \\
\hline \multicolumn{6}{|l|}{ Impoundment effects } \\
\hline Upstream dam site, UDS (categories 1-5) & 1 & - & 1 & - & Increase \\
\hline \multicolumn{6}{|l|}{ Municipal and industrial impacts } \\
\hline Effluent load generated by human population & & & & & Increase \\
\hline Biochemical oxygen demand, $\mathrm{BOD}_{5}\left(\mathrm{tyr}^{-1}\right)$ & 376.7 & 543.7 & 532.1 & 1382.4 & \\
\hline Total suspended solids, TSS $\left(\mathrm{t} \mathrm{yr}^{-1}\right)$ & 537.1 & 775.3 & 779.0 & 2022.3 & \\
\hline Total nitrogen, Ntot $\left(\mathrm{t} \mathrm{yr}^{-1}\right)$ & 75.2 & 108.5 & 104.8 & 276.0 & \\
\hline Total phosphorus, Ptot $\left(\mathrm{tyr}^{-1}\right)$ & 22.9 & 33.1 & 31.8 & 84.0 & \\
\hline Effluent load generated by industrial activities & & & & & Increase \\
\hline Total suspended solids, indTSS $\left(\mathrm{t} \mathrm{yr}^{-1}\right)$ & 1.02 & 0.14 & 1.17 & 0.38 & \\
\hline Chemical oxygen demand, indCQO, $\left(\mathrm{t} \mathrm{yr}^{-1}\right)$ & 1.02 & 0.14 & 1.22 & 0.54 & \\
\hline Number of wine-cellars, Wcel & 1.8 & 3.3 & 1.4 & 3.5 & Increase \\
\hline Number of mines, Min & 0.6 & 1.6 & 0.2 & 0.5 & Increase \\
\hline $\begin{array}{l}\text { Number of inert matter extraction industries, } \\
\text { Inert }\end{array}$ & 6.5 & 11.1 & 0.8 & 1.7 & Increase \\
\hline
\end{tabular}

${ }^{a}$ Modal values (bold numbers) are shown for the group of categorical variables.

set of statistically independent environmental variables related to the benthic assemblages. Data were standardized for environmental variables and by a non-linear procedure for taxa $(\log x+1)$.

The remaining environmental variables were analysed in order to determine their relationship with geographical patterns. For this purpose, seven alternative a priori site classifications (clusters of sites) based on altitude, catchment area, mean catchment slope, latitude, stream order, mean daily air temperature and catchments were tested by discriminant function analysis (DA). Thus, the classification that presented the fewest cases misclassified was selected for further tests, a technique used by Barbour et al. (1996). The package STATISTICA 5.6 (C) (Statsoft, 2001) was used to achieve this selection.

Non-metric multidimensional scaling (n-MDS) analysis, an ordination method based on a rank order of Bray-Curtis similarities of benthic data between sites, allowed comparison between the previous classification of sites produced by the environmental variables with the zonation patterns displayed by this fauna. This analysis clarifies the data when species composition is determined by factors other than position along a specific gradient (De'ath, 1999). The n-MDS was computed from transformed $(\log x+1)$ species abundances using the package PRIMER 5 (Clarke and Gorley, 2001). Such a classification allowed an independent treatment of each group of sites so that the selection of variables could be made within them by performing new CCAs. Variables that were not consistent in explaining the variance of taxa among those groups were discarded. 
To ensure that only those variables that are good indicators of human impacts were chosen and, consequently, to obtain an index independent of stream typology, Pearson correlations were made between distance from source of all sites $(n=90)$ and the preselected environmental variables.

A set of undisturbed sites is required to establish regional reference conditions for comparisons of metrics (Barbour et al., 1996). Using an n-MDS for each group of sites on the basis of their macroinvertebrate composition, an a posteriori approach to classifying sites along a gradient of human disturbance can be made by identifying groups of reference and modified sites. Refinement and confirmation of the site classes were accomplished through comparisons of physical and chemical data collected in each location with the norm of the INAG that defines the use of water for multiple purposes in different classes. This norm is based in 27 parameters that describe the principal nutrients and micropollutants. Thus, a site was considered unimpaired if it belonged to class A and impaired if it belonged to classes D or E.

Once the reference sites and most of the modified sites had been clearly defined, they were used to test the sensitivity of the final variables within catchments. The ability of each environmental variable to discriminate between stressed and unstressed conditions was evaluated according to the method described by Barbour et al. (1996), which is based on the degree of interquartile overlap in 'box-and-whisker' plots. If there is minimal or no overlap between the distributions then the variable can be considered to have a strong discriminatory power, but if the overlap is considerable then the variable is discarded.

\section{Index development}

After restricting the number of variables, the structure of the Habitat Condition Index (HCI) required two further steps:

1. Definition of the scoring criteria for each variable within each catchment via standardization to unitless scores to guarantee that each variable has the same value and importance even though they have different scales. Five scores were considered by using the appropriate quartile of the reference distribution (25th or 75th percentile if variables decrease or increase with impairment respectively-see Table 2). Thus, using the appropriate percentile as the threshold, values that are closest to this percentile receive higher scores (4 and 5), and those having a greater deviation receive lower scores (1 to 3 ). The final value of HCI resulted from the sum of core variable scores for each separate catchment.

2. Definition of the HCI categories related to the various levels of impairment. The threshold to delimit impaired versus unimpaired conditions was that for the moderate versus good status, which corresponds to the 25 th quartile. The other condition classes resulted from equidistant sectioning of the remaining index amplitude.

The flow chart of the main steps involved in the construction of the HCI is shown in Figure 2.

\section{RESULTS}

\section{Selection of variables and sensitivity analysis}

CCA, together with the examination of individual VIFs, suggests that 40 candidate variables make a statistically significant contribution to the variability of invertebrate assemblage (Table 3). Seven belong to the group of regional variables. Six (three at a regional scale (SO, A(cat) and $\mathrm{Sb}$ ) and three at a lower local scale (Altitude, Lat and Tair)) are typological descriptors consequently eliminated from the group of the remaining 40 variables. These six typological variables were used together with the catchment to classify sites into discrete groups to detect major geographical patterns. The remaining 34 variables were used to formulate the habitat index. 


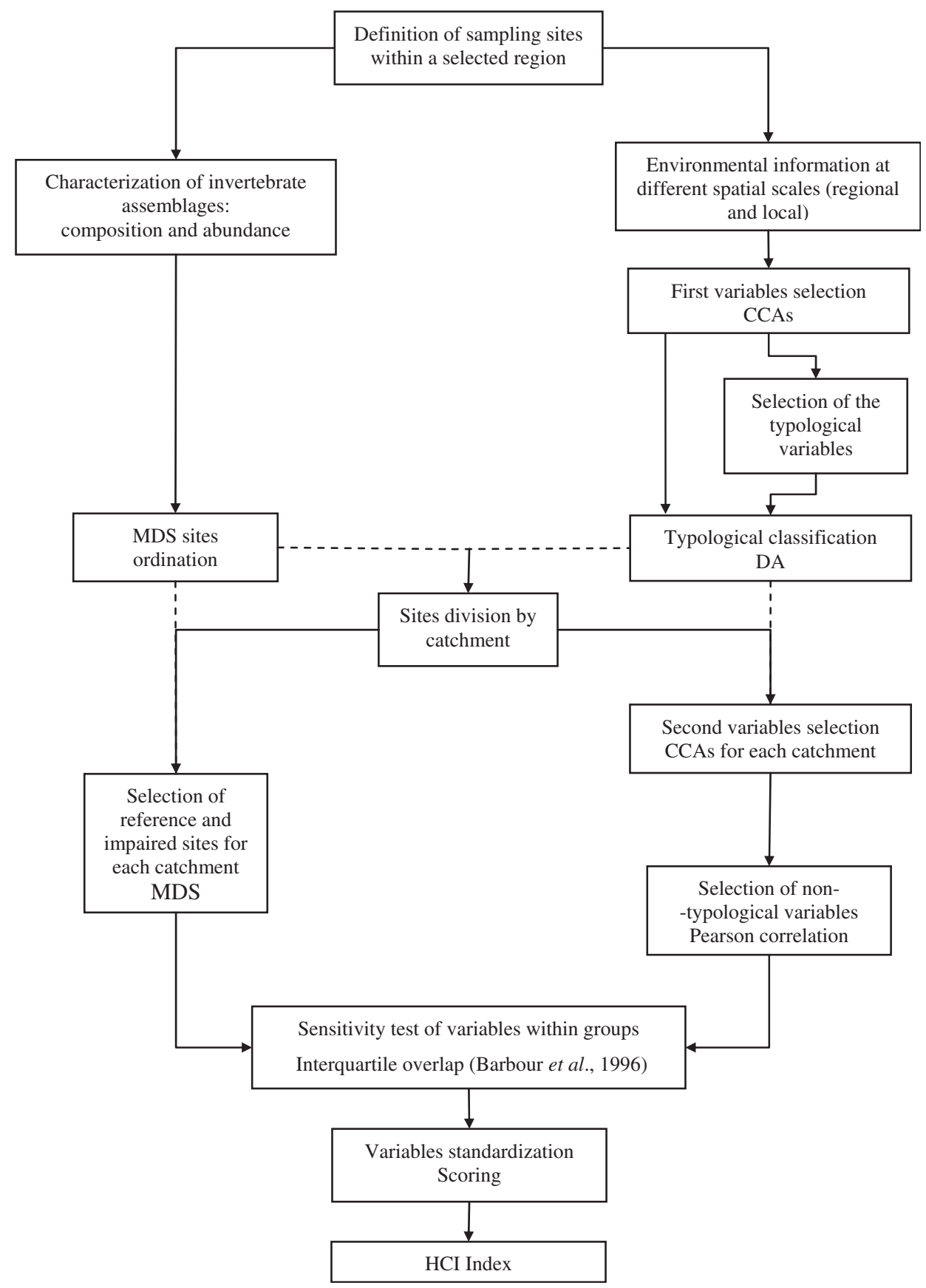

Figure 2. Main steps in the development of the HCI to assess the environmental disturbance of river sites.

The two RBDs considered (NW and Douro catchments) gave the most appropriate classification of the stream networks. This partition resulted in a $0 \%$ misclassification rate of sites, enhancing the discriminatory power of the geographical patterns of the streams (Table 4). 
Table 3. Preselected variables after the accomplishment of CCAs. Variables marked with an asterisk are descriptors of natural variability of the rivers (ecotypological variables). Regional variables are in bold type

\begin{tabular}{llll}
\hline$h$ & SLS & IRS & Altitude* \\
hmax & pH & RR & Lat* \\
$v$ & $\mathrm{O}_{2}$ & QBR & Tair* \\
vmax & temp & RZS & SO* $^{*}$ \\
$w$ & turb & Debris & A (cat)* \\
$w / h$ & cond & MLU & Sb* \\
$\%$ domS & \%aquC & LUS & Hard/Soft \\
HMS & $\%$ ripC & US & \%Ba \\
MC & $\%$ anerb & anthP & Ptot \\
Ss & SAV & Bank alt & Inert \\
\hline
\end{tabular}

Table 4. Results of discriminant analysis of ecotypological variables (alternative classifications) for candidate environmental variables

\begin{tabular}{llc}
\hline Classification model & $\begin{array}{l}\text { Multivariate } \\
p \text {-value }\end{array}$ & $\begin{array}{l}\text { Discriminant } \\
\text { misclassification } \\
\text { rate }(\%)\end{array}$ \\
\hline Altitude $(\leqslant 200 \mathrm{~m} />200 \mathrm{~m})$ & 0.0190 & 10 \\
Altitude $(\leqslant 400 \mathrm{~m} />400 \mathrm{~m})$ & 0.0009 & 7 \\
Altitude $(\leqslant 500 \mathrm{~m} />500 \mathrm{~m})$ & 0.0202 & 13 \\
Catchment area $\left(<1000 \mathrm{~km}^{2} / \geqslant 1000 \mathrm{~km}^{2}\right)$ & 0.0001 & 2 \\
Catchment area $\left(<100 \mathrm{~km}^{2} / 100-1000 \mathrm{~km}^{2} />1000 \mathrm{~km}^{2}\right)$ & 0.0000 & 12 \\
Mean catchment slope $(\leqslant 0.5 />0.5)$ & 0.2022 & 18 \\
Latitude $(<500000 \mathrm{~m} / \geqslant 500000 \mathrm{~m})$ & 0.0011 & 10 \\
Stream order $(1-3 / 4-6)$ & 0.0005 & 6 \\
Mean daily air temperature $\left(\leqslant 12.5^{\circ} \mathrm{C} / \geqslant 15^{\circ} \mathrm{C}\right)$ & 0.1053 & 24 \\
RBD (NW/Douro) & 0.0000 & 0 \\
\hline
\end{tabular}

The n-MDS ordination of invertebrate species composition displayed a similar separation into two basin groups, overlapping the RBD division (Figure 3) and confirming that the benthic communities display different assemblages in each region.

A further refinement of variables took place for each catchment through another CCA and resulted in the elimination of nine environmental variables (hmax, w, Ss, turb, RR, RZS, Hard/Soft, Ptot, Inert). Table 5 shows the Pearson correlation coefficients for the remaining 25 variables. Environmental variables that exhibited a high correlation with the longitudinal gradient expressed by distS $(p<0.01)(h, w / h$, temp, $\%$ ripC and IRS) were eliminated because they are sensitive to natural variation and hide the effects of perturbation.

Once the catchments were made evident, n-MDS ordinations were made separately for each one (Figures 4 and 5). It appeared that in both catchments it was possible to define a disturbance gradient, suggesting that the two groups of sites support different invertebrate communities; consequently, this allowed the selection of a group of reference and impaired stations for scoring the candidate variables. Thus, the reference sites, in both catchments, were characterized by a high diversity of species intolerant to disturbance and organic pollution belonging mainly to the Ephemeroptera, Plecoptera, Trichoptera and Coleoptera. In contrast, impaired sites were dominated by Oligochaeta, Gastropoda and Hirudinea, and totally lacked species of Trichoptera, Plecoptera and Odonata.

To assess the discriminatory power of the 20 variables retained from the previous procedures, boxand-whisker plots (Figure 6) were constructed for each catchment. This analysis showed that 


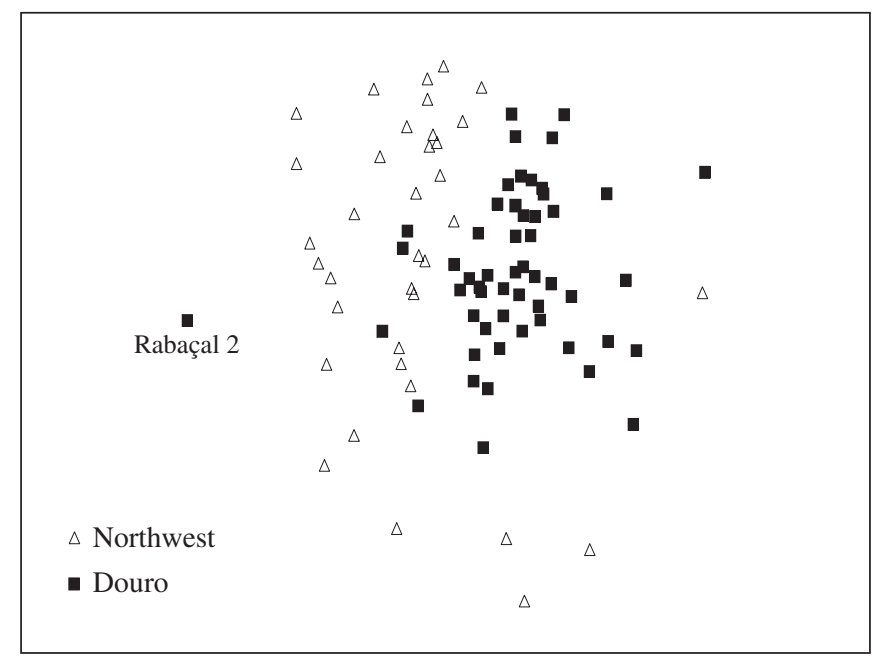

Figure 3. n-MDS ordination plot of all sampled sites showing the separation among catchments (final classification). Rabaçal2, an outlier, was not reclassified because it had a reduced number of organisms, possibly due to difficulty in sampling.

\begin{tabular}{|c|c|}
\hline Variable & $r$ \\
\hline$h$ & $0.4312^{*}$ \\
\hline$v$ & -0.2535 \\
\hline vmax & -0.2606 \\
\hline$w / h$ & $0.2856^{*}$ \\
\hline$\%$ domS & 0.0176 \\
\hline HMS & -0.2142 \\
\hline $\mathrm{MC}$ & -0.1637 \\
\hline SLS & 0.0666 \\
\hline $\mathrm{pH}$ & 0.2261 \\
\hline $\mathrm{O}_{2}$ & 0.1991 \\
\hline temp & $0.3963^{*}$ \\
\hline cond & 0.1770 \\
\hline$\%$ aquC & -0.1127 \\
\hline$\%$ ripC & $-0.4486^{*}$ \\
\hline$\%$ herbC & -0.1756 \\
\hline SAV & -0.1444 \\
\hline IRS & $-0.2810^{*}$ \\
\hline QBR & -0.0377 \\
\hline Debris & -0.2650 \\
\hline MLU & -0.2612 \\
\hline LUS & 0.1206 \\
\hline US & 0.1169 \\
\hline anthP & 0.0292 \\
\hline Bank alt & 0.0493 \\
\hline$\% \mathrm{Ba}$ & -0.1908 \\
\hline
\end{tabular}

only 10 candidate variables were identified as being consistent among catchments. Variables that showed little or no discriminatory ability were eliminated ( $v, \%$ domS, $\mathrm{HMS}, \mathrm{MC}, \mathrm{pH}, \mathrm{O}_{2}, \%$ aquC, \% herbC, US, \%Ba). 


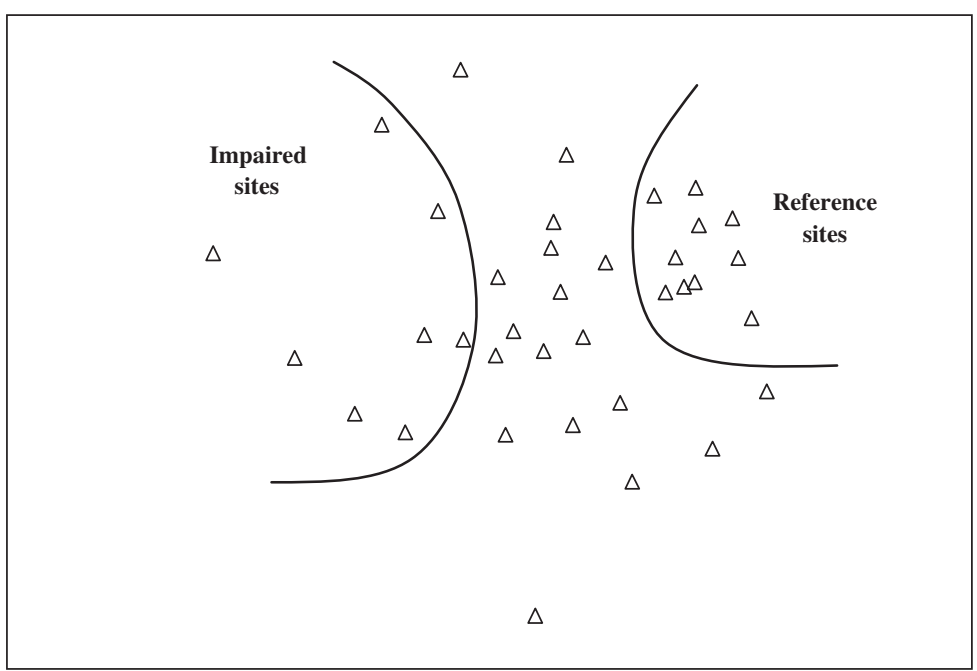

Figure 4. n-MDS ordination plot of sampled sites in the NW catchment. The curved lines are imaginary lines that separate the reference and impaired sites from the remaining ones.

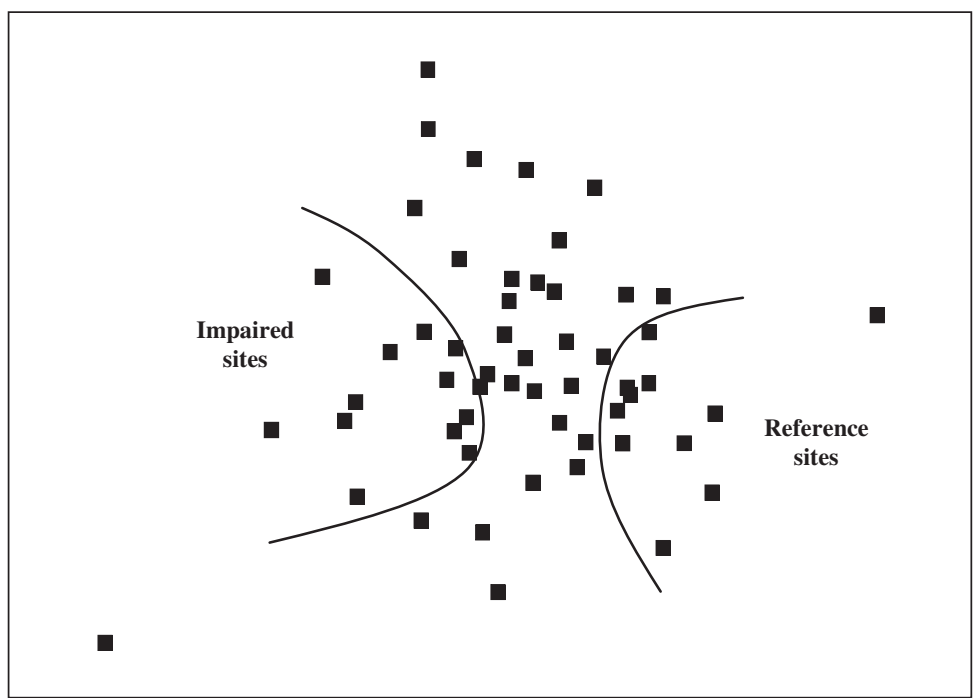

Figure 5. n-MDS ordination plot of sampled sites in the Douro catchment. The curved lines are imaginary lines that separate the reference and impaired sites from the remaining ones.

\section{Development of the HCI}

The standardization of the core environmental variables was accomplished by dividing them into five categories. Given that the environmental variables, such as Bank alt, Debris, LUS, SLS and QBR, were originally assessed by five ordinal rating categories, the same 'pentasection' was used to score the range of all variables.

Scores for the retained variables were obtained by their descriptive statistics (min value, max value and 25th, 50th and 75th percentiles) and appear in Table 6. Through these data it was possible to compute for 

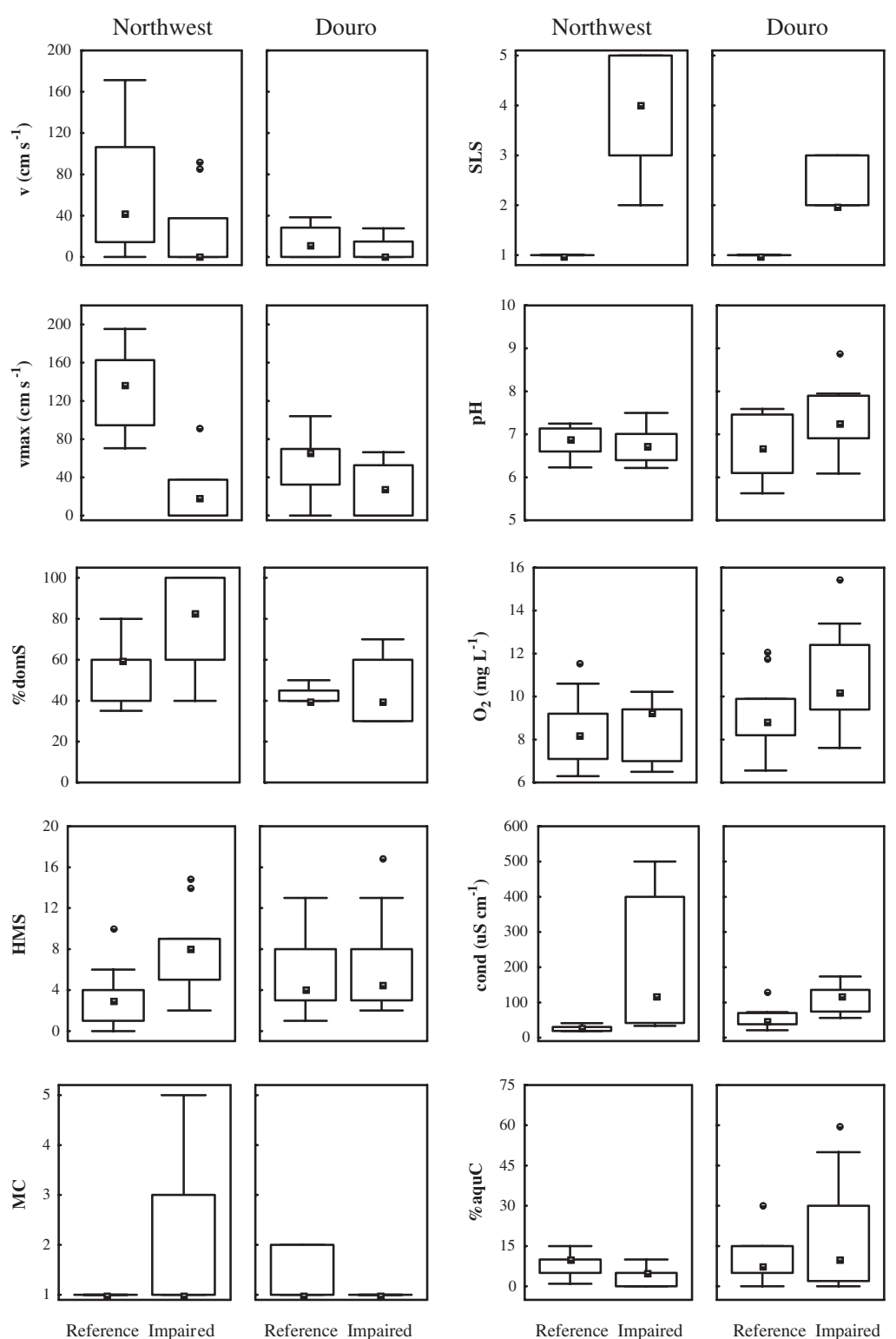

Figure 6. Discriminatory power analysis of the environmental variables for reference and impaired streams. Boxes are interquartile ranges $(25 \%$ ile to $75 \%$ ile), range bars represent maximum and minimum of non-outliers, small squares are medians, and dots are outliers.

the NW and Douro catchments the potential maximum and minimum index scores, which were 50 and 10 respectively. By comparing the index scores of the reference and modified sites within each catchment (Figure 7), the ability of the HCI to separate these groups becomes clear.

Appendix 1 illustrates the field data sheet derived for HCI, which consists of the 10 final variables, six for the reach scale and four for the valley scale, with five conditions for each one. A score of 5 indicates a reference condition, whereas a score of 1 indicates the most disturbed condition. The habitat condition of the stream is calculated by the sum of the scores for all variables. 

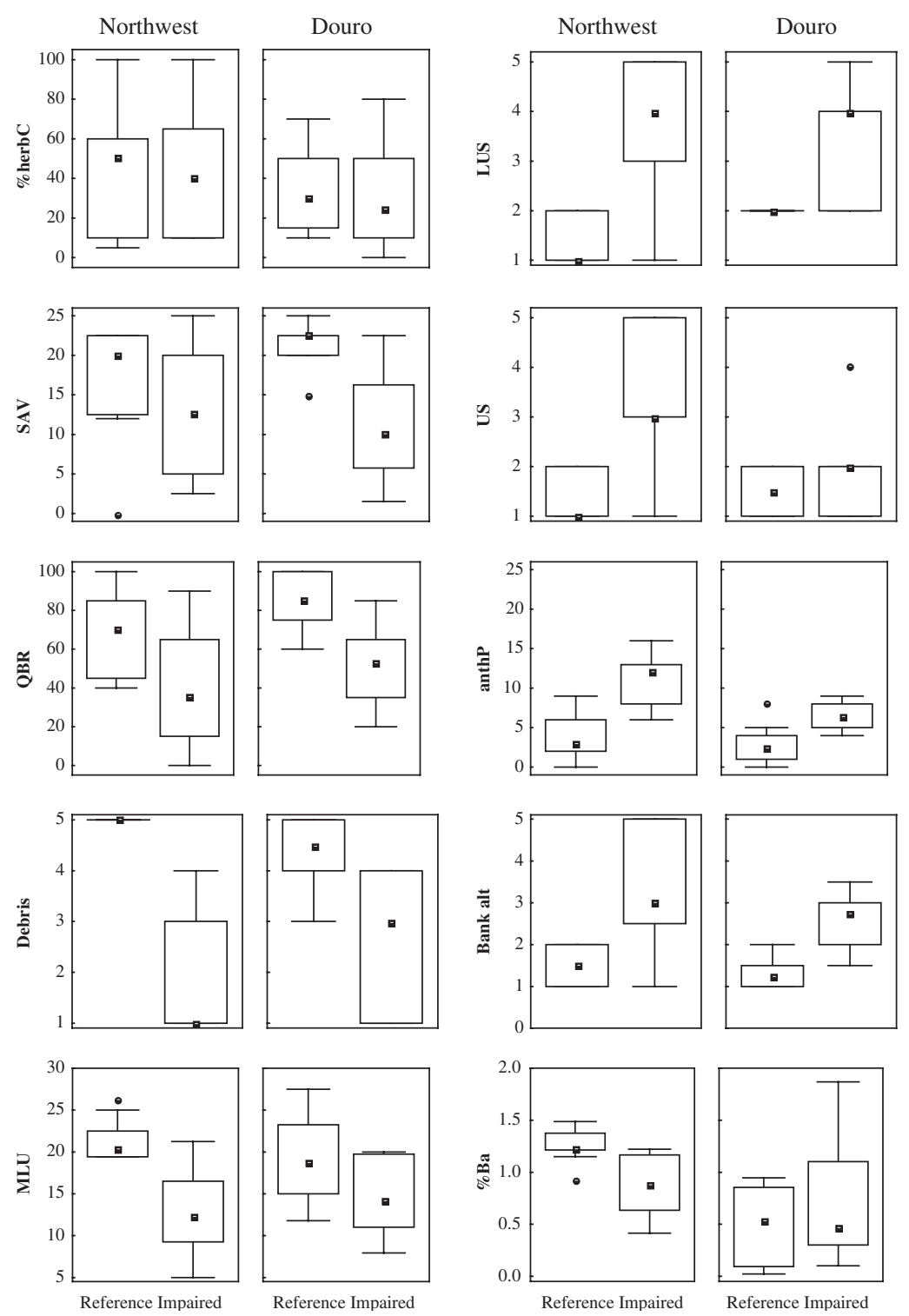

Figure 6. (continued).

\section{DISCUSSION}

The HCI attempts to combine the different levels of the habitat descriptors in order to quantify human impacts on river systems. This objective helps to fulfil a growing need to evaluate ecological integrity at individual sites up to the level of the whole catchment. It also includes the quantification of cumulative effects in order to develop management strategies and establish procedures for conservation and restoration according to the level of observation and management boundaries (Moyle and Marchetti, 1999; Ward et al., 2001; Vølstad et al., 2003). 
HABITAT CONDITION INDEX FOR STREAMS IN PORTUGAL

Table 6. Descriptive statistics and scores for the core environmental variables for the HCI for northern Portugal

\begin{tabular}{|c|c|c|c|c|c|c|c|c|c|c|}
\hline \multirow[t]{2}{*}{ Environmental variable } & \multicolumn{5}{|c|}{ Statistics } & \multicolumn{5}{|c|}{ Score } \\
\hline & Min & $25 \%$ ile & $50 \%$ ile & $75 \%$ ile & Max & 5 & 4 & 3 & 2 & 1 \\
\hline \multicolumn{11}{|l|}{$\mathrm{NW}(n=9)$} \\
\hline $\operatorname{vmax}$ & 70.5 & 94.6 & 137.2 & 162.8 & 195.3 & $\geqslant 146$ & $145-95$ & $94-63$ & $62-31$ & $<31$ \\
\hline $\mathrm{SLS}^{\mathrm{a}}$ & 1.0 & 1.0 & 1.0 & 1.0 & 2.0 & 1 & 2 & 3 & 4 & 5 \\
\hline cond & 18.6 & 19.5 & 25.7 & 30.6 & 41.2 & $\leqslant 15$ & $16-31$ & $32-187$ & $187-343$ & $>343$ \\
\hline SAV & 0.0 & 12.5 & 20.0 & 22.5 & 22.5 & $\geqslant 18$ & $17-12$ & $11-8$ & $7-4$ & $<4$ \\
\hline $\mathrm{QBR}^{\mathrm{a}}$ & 40.0 & 45.0 & 70.0 & 85.0 & 100.0 & $\geqslant 95$ & $75-90$ & $55-70$ & $30-50$ & $0-25$ \\
\hline Debris $^{a}$ & 4.0 & 5.0 & 5.0 & 5.0 & 5.0 & 5 & 4 & 3 & 2 & 1 \\
\hline MLU & 12.2 & 19.4 & 20.3 & 22.5 & 26.3 & $\geqslant 25$ & $24-19$ & $18-14$ & $13-9$ & $8-5$ \\
\hline LUS $^{\mathrm{a}}$ & 1.0 & 1.0 & 1.0 & 2.0 & 2.0 & 1 & 2 & 3 & 4 & 5 \\
\hline anthP & 0.0 & 2.0 & 3.0 & 6.0 & 9.0 & $\leqslant 3$ & $4-6$ & $7-9$ & $10-12$ & $>12$ \\
\hline Bank alt ${ }^{\mathrm{a}}$ & 1.0 & 1.0 & 1.5 & 2.0 & 2.0 & 1 & 2 & 3 & 4 & 5 \\
\hline \multicolumn{11}{|l|}{ Douro $(n=10)$} \\
\hline vmax & 0.0 & 32.6 & 66.4 & 69.8 & 104.1 & $\geqslant 69$ & $68-33$ & $32-22$ & $21-11$ & $<11$ \\
\hline $\mathrm{SLS}^{\mathrm{a}}$ & 1.0 & 1.0 & 1.0 & 1.0 & 2.0 & 1 & 2 & 3 & 4 & 5 \\
\hline cond & 21.2 & 38.0 & 49.5 & 70.0 & 129.9 & $\leqslant 35$ & $36-70$ & $71-168$ & $169-266$ & $>266$ \\
\hline SAV & 10.0 & 20.0 & 22.5 & 22.5 & 25.0 & $\geqslant 23$ & $22-20$ & 19-14 & $13-7$ & $<7$ \\
\hline $\mathrm{QBR}^{\mathrm{a}}$ & 60.0 & 75.0 & 85.0 & 100.0 & 100.0 & $\geqslant 95$ & $75-90$ & $55-70$ & $30-50$ & $0-25$ \\
\hline Debris $^{a}$ & 3.0 & 4.0 & 4.5 & 5.0 & 5.0 & 5 & 4 & 3 & 2 & 1 \\
\hline MLU & 11.8 & 15.0 & 18.8 & 23.3 & 27.5 & $\geqslant 22$ & $21-15$ & $14-12$ & $11-9$ & $8-5$ \\
\hline LUS $^{\mathrm{a}}$ & 1.0 & 2.0 & 2.0 & 2.0 & 4.0 & 1 & 2 & 3 & 4 & 5 \\
\hline anthP & 0.0 & 1.0 & 2.5 & 4.0 & 8.0 & $\leqslant 2$ & $3-4$ & $5-8$ & $9-12$ & $>12$ \\
\hline Bank alt ${ }^{\mathrm{a}}$ & 1.0 & 1.0 & 1.3 & 1.5 & 2.0 & 1 & 2 & 3 & 4 & 5 \\
\hline
\end{tabular}

${ }^{a}$ Variables originally 'pentasectioned' according to a gradient of perturbation.

Three factors for assessing physical habitat in large catchments need to be addressed: (a) the survey time that is required, especially when habitat assessment is done across a range of spatial scales (Maddock, 1999); (b) knowledge of the relationship between the biota and measured variables; and (c) the character of the variables. These aspects were considered during HCI development: the environmental variables do not require extensive field work; their selection was made by crossing biological and environmental data matrices through CCA (Table 3); and the scores derived reflected the disturbance character of sites (established by the n-MDS; Figure 4). Moreover, the HCI eliminated the redundant variables through the successive CCAs and adopted exclusively those that exhibited an independence from the natural variation (Table 5). In addition, it took into account the environmental characteristics of the two main catchments by a differential scoring of variables, although it must be recognized that this separation could be the result of the different years in which these areas were sampled. The end product was a simple index that avoids the high costs of surveying two spatial scales (habitat and river corridor) and which exhibits a clear separation of sites according to the degree of human impact (Figure 6). The philosophy of the HCI, integrating the biotic and abiotic components, also led to the development of indices such as ISC (Index of Stream Condition-Ladson et al., 1998). This index was produced by a research group with expertise in stream ecology, geomorphology, water quality and hydrology, including members from river management bodies and government departments. It comprises an empirical set of indicators that can be used and understood by river managers, with the objective of assessing environmental degradation. Five components are included in the ISC: hydrology, physical form, streamside zone, water quality and aquatic life (benthic fauna), which are scored and weighted, based on the pragmatic judgements of the research group. 

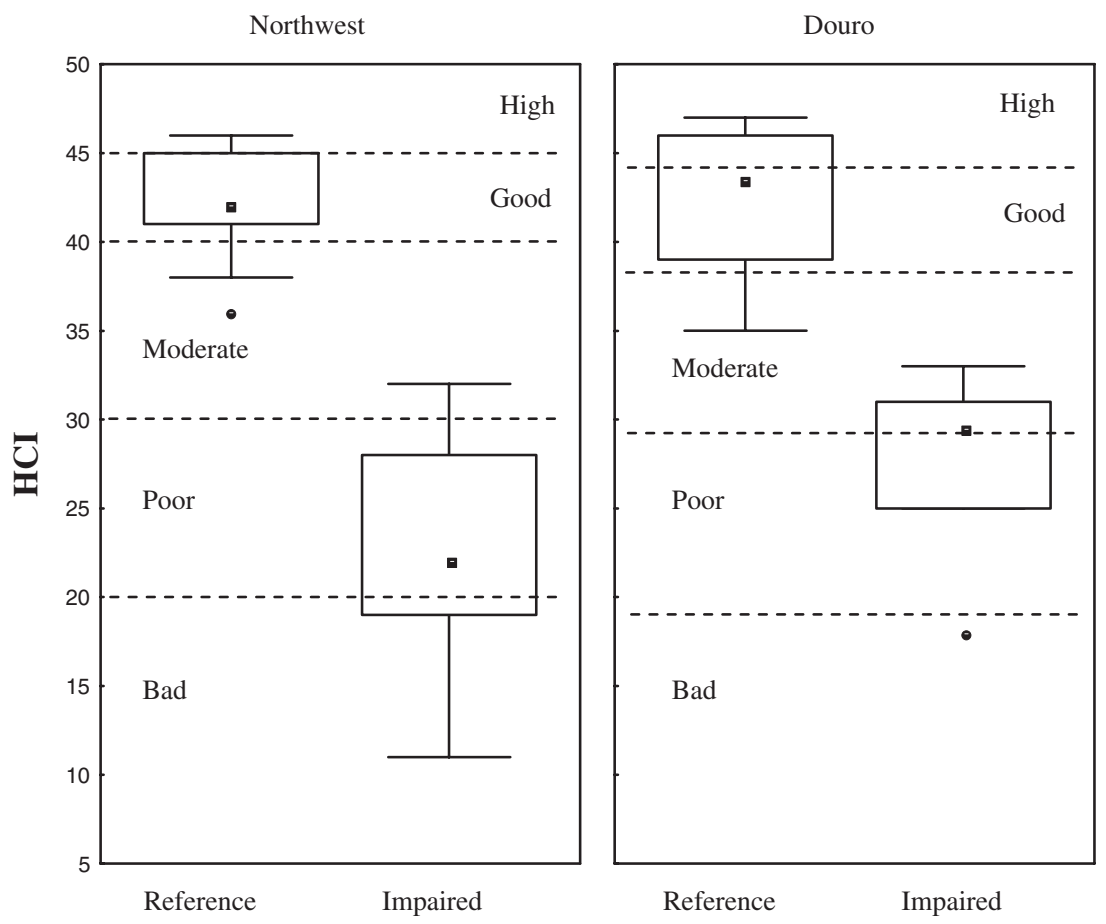

Figure 7. Discriminatory power analysis of the HCI for the NW and Douro catchments. Boxes are interquartile ranges (25\%ile to $75 \%$ ile), range bars represent maximum and minimum of non-outliers, small squares are medians, and dots are outliers. Dotted lines show the scoring ranges of the HCI for each catchment.

Because the number of potential environmental variables to evaluate is vast (from land-use patterns to the micro-habitats within different catchments), the need for such extensive habitat evaluations, instead of relying only on biological assessments, must be questioned. Habitat methods generally display a much lower variability when compared with biological assessments (e.g. macroinvertebrates), making modification thresholds simpler to define and calibrate (Hannaford and Resh, 1995). Biological metrics used to measure stream health, such as IBI or ICI, are generally applied at a reach scale and not at a catchment level. One exception is the W-IBI, developed by Moyle and Randall (1998) and applied by Moyle and Marchetti (1999), that evaluates catchments using metrics based exclusively on native amphibian and fish populations. Increasing the spatial scale of observation may decrease the temporal frequency of the observations, since the variables do not exhibit the intense temporal dynamism linked to short-term impacts and the associated specific resilience of the habitat and micro-habitat (Frissell et al., 1986). However, the fact that the HCI also displays a weak relationship between catchment or regional variables and biota when compared with local variables that characterize the reach or the fluvial habitat cannot be ignored. One explanation is that the effects of perturbation occurring at a catchment level may be reduced by the time they reach the river. Such a buffering influence is probably amplified by a riparian corridor. This is supported by the fact that the HCI includes variables such as structure of arboreal vegetation (SAV) and riparian habitat quality (QBR), which are directly linked to local riparian conditions. Moreover, other variables included in the index are also related to the integrity of this vegetation, such as debris or even conductivity. In reality, the biological integrity of rivers is, to a great extent, dependent on riparian vegetation, both through its influence on stream nutrients, sediment inputs and water temperature, and on the energy sources and flow regime (Naiman, 1992; Sweeney, 1992; Roth et al., 1996). Riparian 
ecotones indeed have the ability to mitigate human impacts at larger scales, since they contribute to the retention of sediments and nutrients (Jaworski, 1993). Removal of riparian vegetation leads to stream-bank erosion, increases the accumulation of fine sediment in the channel, and reduces the recruitment of large woody debris, which plays an important role in retarding sediment transport and providing habitat for aquatic organisms (Jaworski, 1993; Bisson and Bilby, 1998). Thus, it is natural that restoring buffer strips represents an essential tool in river rehabilitation, as they reduce siltation and improve fisheries (mainly herbivore and insectivore populations and also litophilous spawners) (Rabeni and Smale, 1995).

Because the way in which large-scale factors operate may be complex and may interact with local factors (Frissell et al., 1986), there is a considerable skill involved in defining landscape metrics for monitoring landscape change aided by the rapid development of remote sensing and geographic information systems. However, Gergel et al. (2002) remain sceptical and question whether it is worthwhile integrating large-scale variables in monitoring programmes, since it is often difficult to establish cause-effect relationships with biotic communities. The fear is that unnecessary additional costs may accrue, since the process reduces the speed in obtaining data. Broad-scale sampling involves trade-offs between time, effort, and level of detail and can often lead to confusing and contradictory results. For instance, McMahon and Harned (1998) found that land use was a strong predictor of nutrient concentrations in streams at the catchment scale. Johnson et al. (1997) and Cresser et al. (2000) also discovered the same relationship between nutrient loads and land use, but they concluded that these effects are limited to the immediate neighbourhood of an aquatic system. Similarly, Sliva and Williams (2001) concluded that landscape factors do not reflect nutrient variability in the rivers, since local factors (such as point-source pollution) are often better predictors. Snyder et al. (1999) also managed to obtain linear relationships between biological integrity and micro-habitat or riparian structure simply by scoring these descriptors visually. However, these influences depend on the nature of each variable. Sponseller et al. (2001) verified that whereas water chemistry was related to land cover at the scale of the catchment, stream temperature and substratum were related to land cover at the scale of the riparian corridor in the same catchments. Vølstad et al. (2003) found that the risk of local impairment in non-tidal streams increases rapidly with increased urban land-use in the catchment area.

To accommodate the demands of the Water Framework Directive (WFD), which guides river management at the catchment scale, additional research will be necessary to include variables at this level in the HCI with obvious linkages to the aquatic biota. At present, the HCI is being used as a screening method for selecting WFD reference sites at an affordable cost. Its application will permit validation of the results and will help to make the index more accurate by showing whether there is a significant spatial variation of the parameters included in the HCI between the main catchments. This aspect was possibly confounded in the present work due to the different yearly sampling periods (i.e. Douro in 1997 and NW in 1999).

\section{ACKNOWLEDGEMENTS}

We would like to thank those reviewers whose useful comments substantially improved this paper, especially numerous suggestions from Dr Paul Raven (Environment Agency, UK).

Part of this research was funded by the Program for Establishing the Catchment Plans of North Portugal, under the supervision of INAG.

\section{REFERENCES}

Barbour MT, Gerritsen J, Griffith GE, Frydenborg R, McCarron E, White JS, Bastian ML. 1996. A framework for biological criteria for Florida streams using benthic macroinvertebrates. Journal of the North American Benthological Society 15: 185-211.

Barbour MT, Gerritsen J, Snyder BD, Stribling JB. 1999. Rapid bioassessment protocols for use in streams and wadeable rivers: periphyton, benthic macroinvertebrates and fish. US Environmental Protection Agency, Office of Water, Washington, DC. 2nd ed., EPA 841-B-99-002. 
Bisson PA, Bilby RE. 1998. Organic matter and trophic dynamics. In River Ecology and Management, Naiman RJ, Bilby RE (eds). Springer: New York; 373-391.

Bowlby JN, Roff JN. 1986. Trout biomass and habitat relationships in southern Ontario streams. Transactions of the American Fisheries Society 115: 503-514.

Clarke KR, Gorley RN. 2001. PRIMER v5: User Manual/Tutorial. PRIMER-E Plymouth.

Corkum LD. 1989. Patterns of benthic invertebrate assemblages in rivers of northwestern North America. Freshwater Biology 21: 191-205.

Cresser MS, Smart R, Billett MF, Soulsby G, Neal C, Wade A, Langan S, Edwards AC. 2000. Modelling water chemistry for a major Scottish river from catchment attributes. Journal of Applied Ecology 37: 171-184.

Davis NM, Norris RH, Thoms MC. 2000. Prediction and assessment of local stream habitat features using large-scale catchment characteristics. Freshwater Biology 45: 343-369.

De'ath G. 1999. Principal curves: a new technique for indirect and direct gradient analysis. Ecology 80: $2237-2253$.

Downs PW, Brooks A. 1994. Developing a standard geomorphological approach for the appraisal of river projects. In Integrated River Basin Development, Kirby C, White WR (eds). John Wiley: Chichester; 299-310.

Frissell CA, Liss WJ, Warren CE, Hurley MD. 1986. A hierarchical framework for stream habitat classification: viewing streams in the watershed concept. Environmental Management 10: 199-214.

Gergel SE, Turner MG, Miller JR, Melack JM, Stanley EH. 2002. Landscape indicators of human impacts to riverine systems. Aquatic Science 64: 118-128.

Hannaford MJ, Resh VH. 1995. Variability in macroinvertebrate rapid-bioassessment surveys and habitat assessments in a northern California stream. Journal of the North American Benthological Society 14: 430-439.

Hughes RM, Larsen DP, Mathews DJ, Yoder CO. 1994. Use of ecoregions in biological monitoring. In Biological Monitoring of Aquatic Ecosystems, Loeb SL, Law FM (eds). Lewis: Florida; 125-151.

Imhof JG, Fitzgibbon J, Annable WK. 1996. A hierarchical evaluation system for characterizing watershed ecosystems for fish habitat. Canadian Journal of Fisheries and Aquatic Sciences 53(Supplement 1): 312-326.

Jaworski A. 1993. The application of the ecotone concept in defining nutrient management requirements for the upper Potomac River basin. Hydrobiologia 251: 341-349.

Johnson LB, Richards C, Host GE, Arthur JW. 1997. Landscape influence on water chemistry in Midwestern stream ecosystems. Freshwater Biology 37: 193-218.

Jongman RHG, ter Braak CFJ, van Tongeren OFR (eds). 1987. Data Analysis in Community and Landscape Ecology. Pudoc: Wageningen.

Ladson AR, White LJ, Doolan JA, Finlaysons BL, Hart BT, Lake PS, Tilleard JW. 1998. Development and testing of an index of stream condition for waterway management in Australia. Freshwater Biology 41: 453-468.

Maddock I. 1999. The importance of physical habitat assessment for evaluating river health. Freshwater Biology 41: 373-391.

McIver J, Starr L. 2001. Restoration of degraded lands in the interior of Columbia River basin: passive vs. active approaches. Forest Ecology and Management 153: 15-28.

McMahon G, Harned DA. 1998. Effect of environmental setting on sediment, nitrogen and phosphorus concentrations in Albermarle-Pamlico drainage basin, North Carolina and Virginia, USA. Environmental Management 22: 887-903.

Milhous RT, Wegner DL, Waddle T. 1984. Users guide to the Physical Habitat Simulation System (PHABSIM). Instream Information Paper 11. US Fish and Wildlife Service, FWS/OBS-81/13.

Milner NJ, Hemsworth RJ, Jones BE. 1985. Habitat evaluation as a fisheries management tool. Journal of Fish Biology 27: $85-180$.

Milner NJ, Wyatt RJ, Broad K. 1998. HABSCORE-applications and future developments of related habitat models. Aquatic Conservation: Marine and Freshwater Ecosystems 8: 633-644.

Moyle PB, Marchetti MP. 1999. Applications of indices of biotic integrity to California streams and watersheds. In Assessing the Sustainability and Biological Integrity of Water Resources Using Fish Communities, Simon TP (ed.). CRC Press: Boca Raton, FL; 367-380.

Moyle PB, Randall PJ. 1998. Evaluating the biotic integrity of watersheds in Sierra Nevada, California. Conservation Biology 12: 1318-1326.

Munné A, Solà C, Prat N. 1998. QBR: un índice rápido para la evaluación de la calidad de los ecosistemas de ribera. Tecnologia del Agua 175: 20-37.

Naiman RJ. 1992. Watershed Management: Balancing Sustainability and Environmental Change. Springer-Verlag: New York.

Oberdorff T, Pont D, Hugueny B, Chessel D. 2001. A probabilistic model characterizing fish assemblages of French rivers: a framework for environmental assessment. Freshwater Biology 46: 399-415.

Oberdorff T, Pont D, Hugueny B, Porchers JP. 2002. Development and validation of a fish-based index for assessment of "river-health" in France. Freshwater Biology 47: 1720-1734. 
Plafkin JL, Barbour MT, Porter KD, Gross SK, Hughes RM. 1989. Rapid bioassessment protocols for use in streams and rivers: benthic macroinvertebrates \& fish. US Environmental Protection Agency. Assessment and Watershed Protection Division, Washington, DC. EPA/440/4-89/001.

Rabeni CF, Smale MA. 1995. Effects of siltation on stream fishes and the potential mitigation role of the buffering riparian zone. Hydrobiologia 303: 211-219.

Raven PJ, Fox P, Everard M, Holmes NTH, Dawson FH. 1997. River Habitat Survey: a new system for classifying rivers according to their habitat quality. In Freshwater Quality: Defining the Indefinable?, Boon PJ, Howell DL (eds). The Stationery Office: Edinburgh; 215-234.

Reeves GH, Hohler DB, Hansen BE, Everest FH, Sedell JR, Hickman TL, Shively D. 1997. Fish habitat restoration in the Pacific Northwest: Fish Creek of Oregon. In Watershed Restoration: Principles and Practices, Williams JE, Wood CA, Dombeck MP (eds). American Fisheries Society: Bethesda, MD; 335-359.

Reynoldson TN, Norris RH, Resh VH, Day KE, Rosenberg DM. 1997. The reference condition: a comparison of multimetric approaches to assess water quality impairment using benthic invertebrates. Journal of the North American Benthological Society 16: 833-852.

Roth NE, Allan JD, Erickson DL. 1996. Landscape influences on stream biotic integrity assessed at multiple spatial scales. Landscape Ecology 11: 141-156.

Schumm SA. 1956. Evolution of drainage systems and slopes in Badlands at Perth Amboy, New Jersey. Geological Society of America Bulletin 67: 597-646.

Scott MC, Hall LW. 1997. Fish assemblage as indicators of environmental degradation in Maryland coastal plain streams. Transactions of the American Fisheries Society 126: 349-360.

Sliva L, Williams DD. 2001. Buffer zone versus whole catchment approaches in studying landuse on river water quality. Water Research 35: 3462-3472.

Snyder BD, Stribling JB, Barbour MT, Missimer CL. 1999. Integrating assessments of fish and macroinvertebrate assemblages and physical habitat condition in Pennsylvania. In Assessing the Sustainability and Biological Integrity of Water Resources Using Fish Communities, Simon T (ed.). CRC Press: Boca Raton; 639-652.

Sponseller RA, Benfield EF, Valett HM. 2001. Relationships between land use, spatial scale and stream macroinvertebrate communities. Freshwater Biology 46: 1409-1424.

StatSoft. 2001. STATISTICA for Windows (Computer Program Manual). StatSoft, Inc.: Tulsa, OK.

Sweeney BW. 1992. Streamside forest and the physical, chemical and trophic characteristics of piedmont streams in eastern North America. Water Science and Technology 26: 2653-2673.

Ter Braak CJF. 1986. Canonical correspondence analysis: a new eigenvector technique for multivariate direct gradient analysis. Ecology 67: 1167-1179.

Ter Braak CJF, Prentice IC. 1988. A theory of gradient analysis. Advances in Ecological Research 18: $271-317$.

Ter Braak CJF, Smilauer P. 1998. CANOCO Reference Manual and User's Guide to Canoco for Windows: Software for Canonical Community Ordination (version 4). Microcomputer Power: Ithaca, NY.

Vølstad JH, Roth NE, Mercurio G, Southerland MT, Strebel DE. 2003. Using environmental stressor information to predict the ecological status of Maryland non-tidal streams as measured by biological indicators. Environmental Monitoring and Assessment 84: 219-242.

Ward JV, Tockner K, Uehlinger U, Malard F. 2001. Understanding natural patterns and processes in river corridors as the basis for effective river restoration. Regulated Rivers: Research \& Management 17: 311-323.

Wright JF. 1995. Development and use of a system for predicting the macroinvertebrate fauna in flowing waters. Australian Journal of Ecology 20: 181-197. 


\section{APPENDIX. HCI FIELD DATA SHEET}

\section{Details of sampling}

\begin{tabular}{|l|l|}
\hline River basin: & Coordinates: \\
\hline Stream name: & Weather conditions: \\
\hline Station: & Photo no: \\
\hline Date: & Filled by: \\
\hline Time: & \\
\hline
\end{tabular}

\begin{tabular}{|c|c|c|c|c|c|c|}
\hline \multirow{2}{*}{$\begin{array}{l}\text { Parameter to } \\
\text { be evaluated }\end{array}$} & \multirow[t]{2}{*}{ Catchment } & \multicolumn{5}{|c|}{ Condition class } \\
\hline & & High & Good & Moderate & Poor & $\mathrm{Bad}$ \\
\hline \multirow[t]{4}{*}{$\begin{array}{l}\text { 1. Maximum } \\
\text { water velocity } \\
\text { (Reach scale) }\end{array}$} & \multirow[t]{2}{*}{ NW } & $\begin{array}{l}\text { Velocity } \\
\text { greater than } \\
145 \mathrm{~cm} \mathrm{~s}^{-1}\end{array}$ & $95-145 \mathrm{~cm} \mathrm{~s}^{-1}$ & $63-94 \mathrm{~cm} \mathrm{~s}^{-1}$ & $31-62 \mathrm{~cm} \mathrm{~s}^{-1}$ & $\begin{array}{l}\text { Less than } \\
31 \mathrm{~cm} \mathrm{~s}^{-1}\end{array}$ \\
\hline & & 5 & 4 & 3 & 2 & 1 \\
\hline & \multirow[t]{2}{*}{ Douro } & 5 & 4 & 3 & 2 & 1 \\
\hline & & $\begin{array}{l}\text { Velocity } \\
\text { greater than } \\
68 \mathrm{~cm} \mathrm{~s}^{-1}\end{array}$ & $68-33 \mathrm{~cm} \mathrm{~s}^{-1}$ & $32-22 \mathrm{~cm} \mathrm{~s}^{-1}$ & $21-11 \mathrm{~cm} \mathrm{~s}^{-1}$ & $\begin{array}{l}\text { Less than } \\
11 \mathrm{~cm} \mathrm{~s}^{-1}\end{array}$ \\
\hline \multirow[t]{4}{*}{$\begin{array}{l}\text { 2. Conductivity } \\
\text { (Reach scale) }\end{array}$} & \multirow[t]{2}{*}{ NW } & $\begin{array}{l}\text { Conductivity } \\
\leqslant 15 \mu \mathrm{S} \mathrm{cm}^{-1}\end{array}$ & $16-31 \mu \mathrm{S} \mathrm{cm}^{-1}$ & $\begin{array}{l}32- \\
187 \mu \mathrm{S} \mathrm{cm}^{-1}\end{array}$ & $\begin{array}{l}188- \\
343 \mu \mathrm{S} \mathrm{cm}^{-1}\end{array}$ & $\begin{array}{l}\text { Greater than } \\
343 \mu \mathrm{S} \mathrm{cm}^{-1}\end{array}$ \\
\hline & & 5 & 4 & 3 & 2 & 1 \\
\hline & \multirow[t]{2}{*}{ Douro } & 5 & 4 & 3 & 2 & 1 \\
\hline & & $\begin{array}{l}\text { Conductivity } \\
\leqslant 35 \mu \mathrm{S} \mathrm{cm}^{-1}\end{array}$ & $36-70 \mu \mathrm{S} \mathrm{cm}^{-1}$ & $\begin{array}{l}71- \\
168 \mu \mathrm{S} \mathrm{cm}^{-1}\end{array}$ & $\begin{array}{l}169- \\
266 \mu \mathrm{S} \mathrm{cm}^{-1}\end{array}$ & $\begin{array}{l}\text { Greater than } \\
266 \mu \mathrm{S} \mathrm{cm}^{-1}\end{array}$ \\
\hline \multirow[t]{2}{*}{$\begin{array}{l}\text { 3. Structure } \\
\text { of arboreal } \\
\text { vegetation } \\
\text { Both banks } \\
\text { should be } \\
\text { taken into } \\
\text { account } \\
\text { (Reach scale) }\end{array}$} & \multirow[t]{2}{*}{$\begin{array}{l}\text { NW and } \\
\text { Douro }\end{array}$} & $\begin{array}{l}\text { Continuous } \\
\text { arboreal } \\
\text { vegetation or } \\
\text { disruptions } \\
\text { not evident or } \\
\text { minimal }\end{array}$ & $\begin{array}{l}75-90 \% \text { of the } \\
\text { riparian zone } \\
\text { covered by } \\
\text { trees }\end{array}$ & $\begin{array}{l}40-75 \% \text { of the } \\
\text { riparian zone } \\
\text { covered by } \\
\text { small thickets }\end{array}$ & $\begin{array}{l}\text { Disruption } \\
\text { obvious, trees } \\
\text { regularly } \\
\text { spaced. More } \\
\text { than } 60 \% \text { of } \\
\text { the riparian } \\
\text { zone without } \\
\text { trees }\end{array}$ & $\begin{array}{l}\text { All trees have } \\
\text { been removed } \\
\text { or existence of } \\
\text { isolated trees }\end{array}$ \\
\hline & & 5 & 4 & 3 & 2 & 1 \\
\hline \multirow[t]{2}{*}{$\begin{array}{l}\text { 4. } \mathbf{Q B R} \mathbf{R}^{\mathbf{b}} \\
\text { (Reach scale) }\end{array}$} & \multirow[t]{2}{*}{$\begin{array}{l}\text { NW and } \\
\text { Douro }\end{array}$} & $\begin{array}{l}\text { Riparian } \\
\text { ecosystem } \\
\text { without } \\
\text { alterations, } \\
\text { natural state }\end{array}$ & $\begin{array}{l}\text { Riparian } \\
\text { ecosystem } \\
\text { slightly } \\
\text { impaired, } \\
\text { good quality }\end{array}$ & $\begin{array}{l}\text { Beginning of } \\
\text { an important } \\
\text { alteration, } \\
\text { acceptable } \\
\text { quality }\end{array}$ & $\begin{array}{l}\text { Great } \\
\text { alteration, bad } \\
\text { quality }\end{array}$ & $\begin{array}{l}\text { Extreme } \\
\text { degradation, } \\
\text { very bad } \\
\text { quality }\end{array}$ \\
\hline & & 5 & 4 & 3 & 2 & 1 \\
\hline
\end{tabular}




\begin{tabular}{|c|c|c|c|c|c|c|}
\hline \multirow[t]{2}{*}{$\begin{array}{l}\text { 5. Debris } \\
\text { (Reach scale) }\end{array}$} & \multirow[t]{2}{*}{$\begin{array}{l}\text { NW and } \\
\text { Douro }\end{array}$} & $\begin{array}{l}\text { Well supplied } \\
\text { with CPOM }\end{array}$ & $\begin{array}{l}\text { Similar } \\
\text { amounts of } \\
\text { FPOM and } \\
\text { CPOM }\end{array}$ & $\begin{array}{l}\text { More FPOM } \\
\text { than CPOM }\end{array}$ & $\begin{array}{l}\text { Only FPOM } \\
\text { present }\end{array}$ & $\begin{array}{l}\text { Presence of } \\
\text { mud }\end{array}$ \\
\hline & & 5 & 4 & 3 & 2 & 1 \\
\hline \multirow[t]{2}{*}{$\begin{array}{l}\text { 6. Bank } \\
\text { alteration } \\
\text { Both banks } \\
\text { should be } \\
\text { taken into } \\
\text { account } \\
\text { (Reach scale) }\end{array}$} & \multirow[t]{2}{*}{$\begin{array}{l}\text { NW and } \\
\text { Douro }\end{array}$} & $\begin{array}{l}\text { Banks in their } \\
\text { natural state. } \\
\text { No human } \\
\text { activities (e.g. } \\
\text { grazing, inert } \\
\text { extraction, } \\
\text { channelization, } \\
\text { hydraulic } \\
\text { structures, } \\
\text { linearization, } \\
\text { impoundments, } \\
\text { vegetation } \\
\text { cut...) }\end{array}$ & $\begin{array}{l}\text { Human } \\
\text { activities have } \\
\text { impacted the } \\
\text { banks only } \\
\text { minimally }\end{array}$ & $\begin{array}{l}\text { Moderate } \\
\text { impact in the } \\
\text { banks due to } \\
\text { human } \\
\text { activities }\end{array}$ & $\begin{array}{l}\text { Great } \\
\text { alterations of } \\
\text { the banks }\end{array}$ & $\begin{array}{l}\text { Channelization } \\
\text { or banks } \\
\text { completely } \\
\text { changed due to } \\
\text { human activities }\end{array}$ \\
\hline & & 5 & 4 & 3 & 2 & 1 \\
\hline \multirow[t]{2}{*}{$\begin{array}{l}\text { 7. Sediment } \\
\text { load segment } \\
\text { (Valley scale) }\end{array}$} & \multirow[t]{2}{*}{$\begin{array}{l}\text { NW and } \\
\text { Douro }\end{array}$} & $\begin{array}{l}\text { Little, or } \\
\text { absence of, } \\
\text { enlargement } \\
\text { of islands or } \\
\text { point bars. } \\
\text { Less than } \\
20 \% \text { of the } \\
\text { bottom } \\
\text { affected by } \\
\text { sediment } \\
\text { deposition }\end{array}$ & $\begin{array}{l}20-40 \% \text { of the } \\
\text { bottom } \\
\text { affected by } \\
\text { sediment } \\
\text { deposition. } \\
\text { Slight } \\
\text { deposition in } \\
\text { pools }\end{array}$ & $\begin{array}{l}\text { Moderate } \\
\text { deposition. } \\
>40-60 \% \text { of } \\
\text { the bottom } \\
\text { affected by } \\
\text { sediment } \\
\text { deposition }\end{array}$ & $\begin{array}{l}\text { Substantial } \\
\text { deposits of } \\
\text { fine material } \\
\text { on old and } \\
\text { new bars. } \\
>60-80 \% \text { of } \\
\text { the bottom } \\
\text { affected by } \\
\text { sediment } \\
\text { deposition }\end{array}$ & $\begin{array}{l}\text { High sediment } \\
\text { deposition, } \\
\text { enlargement } \\
\text { of bars or } \\
\text { islands. More } \\
\text { than } 80 \% \text { of } \\
\text { the bottom } \\
\text { changing } \\
\text { frequently }\end{array}$ \\
\hline & & 5 & 4 & 3 & 2 & 1 \\
\hline \multirow[t]{2}{*}{$\begin{array}{l}\text { 8. Marginal } \\
\text { land use } \\
\text { Both slopes } \\
\text { should be } \\
\text { taken into } \\
\text { account }\end{array}$} & \multirow[t]{2}{*}{$\begin{array}{l}\text { NW and } \\
\text { Douro }\end{array}$} & $\begin{array}{l}\text { Untouched } \\
\text { forest or } \\
\text { undisturbed } \\
\text { native } \\
\text { vegetation }\end{array}$ & $\begin{array}{l}\text { Advanced } \\
\text { stadium of } \\
\text { forest } \\
\text { succession } \\
\text { (high } \\
\text { understorey } \\
\text { shrubs) }\end{array}$ & $\begin{array}{l}\text { Intermediate } \\
\text { stadium of } \\
\text { forest } \\
\text { succession } \\
\text { (low } \\
\text { understorey } \\
\text { shrubs and/or } \\
\text { herbaceous } \\
\text { state) } \\
\end{array}$ & $\begin{array}{l}\text { Livestock } \\
\text { pasturing or } \\
\text { extensive } \\
\text { agriculture }\end{array}$ & $\begin{array}{l}\text { Urban area or } \\
\text { intensive } \\
\text { agriculture }\end{array}$ \\
\hline & & 5 & 4 & 3 & 2 & 1 \\
\hline \multirow[t]{2}{*}{$\begin{array}{l}\text { 9. Land-use } \\
\text { segment } \\
\text { Both slopes } \\
\text { should be } \\
\text { taken into } \\
\text { account } \\
\text { (Valley scale) }\end{array}$} & \multirow[t]{2}{*}{$\begin{array}{l}\text { NW and } \\
\text { Douro }\end{array}$} & $\begin{array}{l}\leqslant 10 \% \\
\text { cultivated } \\
\text { land }\end{array}$ & $\begin{array}{l}>10-20 \% \\
\text { cultivated } \\
\text { land }\end{array}$ & $\begin{array}{l}>20-40 \% \\
\text { cultivated } \\
\text { land }\end{array}$ & $\begin{array}{l}>40-60 \% \\
\text { cultivated } \\
\text { land }\end{array}$ & $\begin{array}{l}\text { More than } \\
60 \% \\
\text { cultivated } \\
\text { land }\end{array}$ \\
\hline & & 5 & 4 & 3 & 2 & 1 \\
\hline
\end{tabular}




\begin{tabular}{|c|c|c|c|c|c|c|}
\hline \multirow[t]{2}{*}{$\begin{array}{l}\text { 10. Anthropogenic } \\
\text { perturbation } \\
\text { Both slopes } \\
\text { should be } \\
\text { taken into } \\
\text { account } \\
\text { (Valley scale) }\end{array}$} & \multirow[t]{2}{*}{$\begin{array}{l}\text { NW and } \\
\text { Douro }\end{array}$} & $\begin{array}{l}\text { Hillsides with } \\
\text { no or little } \\
\text { disturbance } \\
\text { caused by } \\
\text { human } \\
\text { activities (e.g. } \\
\text { agriculture, } \\
\text { urban zone, } \\
\text { road beds, } \\
\text { pasture, inert } \\
\text { extraction, } \\
\text { parking lots, } \\
\text { deforestation, } \\
\text { reforestation, } \\
\text { rubbish, clear } \\
\text { cutting...) }\end{array}$ & $\begin{array}{l}\text { Human } \\
\text { activities have } \\
\text { impacted the } \\
\text { hillsides only } \\
\text { minimally }\end{array}$ & $\begin{array}{l}\text { Moderate } \\
\text { impact in the } \\
\text { hillsides due } \\
\text { to human } \\
\text { activities }\end{array}$ & $\begin{array}{l}\text { Obvious } \\
\text { alterations of } \\
\text { the hillsides }\end{array}$ & $\begin{array}{l}\text { Great } \\
\text { deviation } \\
\text { from natural } \\
\text { state of } \\
\text { hillsides }\end{array}$ \\
\hline & & 5 & 4 & 3 & 2 & 1 \\
\hline
\end{tabular}

Final score:

The HCI score for a site is the total of all the parameter scores.

${ }^{a}$ Valley scale: the adjacent area to the river that directly influences the sampled site; this is a segment with $2 \mathrm{~km}(1000 \mathrm{~m}$ upstream and $1000 \mathrm{~m}$ downstream of the sampling site). Reach scale: the sampled site in the stream/river.

${ }^{\mathrm{b}}$ This index is determined through the parameters reported in the original field data sheet (QBR index (Munné et al., 1998): field data sheet). The QBR field data sheet must be completed together with the field data sheet for the HCI. The final score of QBR (which is the addition of four parts) will be put in one of these condition categories according to the original pentasection of scoring ranges.

Five-point scale for indicator measurements. Quality classes, total scores, attributes and colours used for map presentation:

\begin{tabular}{|l|l|l|l|l|}
\hline \multirow{2}{*}{$\begin{array}{l}\text { Quality } \\
\text { class }\end{array}$} & \multicolumn{2}{|c|}{ Score } & \multicolumn{1}{|c|}{ Attributes } & Colour \\
\cline { 2 - 5 } & NW & Douro & & \\
\hline I & $46-50$ & $45-50$ & $\begin{array}{l}\text { High status. Comparable to reference conditions. } \\
\text { Biomonitoring and protection of the existing status }\end{array}$ & Blue \\
\hline II & $41-45$ & $39-44$ & $\begin{array}{l}\text { Good status. Slight deviation from reference condi- } \\
\text { tions. Minor modifications needed }\end{array}$ & Green \\
\hline III & $31-40$ & $30-38$ & $\begin{array}{l}\text { Moderate status. Beginning of appreciable perturba- } \\
\text { tion. Minor alterations needed }\end{array}$ & Yellow \\
\hline IV & $21-30$ & $20-29$ & $\begin{array}{l}\text { Poor status. High levels of degradation of the habitat. } \\
\text { Major alterations needed }\end{array}$ & Orange \\
\hline V & $10-20$ & $10-19$ & $\begin{array}{l}\text { Bad status. Greatest levels of degradation. The habitat } \\
\text { needs a complete structural reorganization }\end{array}$ & Red \\
\hline
\end{tabular}

